SJ Quinney College of Law, University of Utah Utah Law Digital Commons

\title{
Can We Protect the Innocent Without Freeing the Guilty? Thoughts on Innocence Reforms that Avoid Harmful Tradeoffs
}

Paul Cassell

S.J. Quinney College of Law, University of Utah, paul.cassell@law.utah.edu

Follow this and additional works at: http://dc.law.utah.edu/scholarship

Part of the Criminal Law Commons, and the Criminal Procedure Commons

\section{Recommended Citation}

Cassell, P.G., Can We Protect the Innocent Without Freeing the Guilty? Thoughts on Innocence Reforms that Avoid Harmful Tradeoffs in WRONGFUL CONVICTIONS AND THE DNA REVOLUTION: TWENTY-FIVE YEARS OF FREEING THE INNOCENT (ed. Daniel Medwed), Cambridge University Press (2017) 


\title{
CAN We Protect the InNOCEnt Without Freeing the GuILTy? \\ THOUGHTS ON INNOCENCE REFORMS THAT AVOID HARMFUL TRADEOFFS
}

\author{
By Paul G. Cassell ${ }^{1}$ \\ Introduction
}

The other thoughtful Chapters in this book call for action to prevent factually innocent defendants from being convicted at trial. These Chapters quite rightly draw attention to the fundamental importance of the criminal justice system accurately separating the guilty from the innocent. But the Chapters' policy prescriptions, at least in some cases, rest on shakier ground.

In my contribution to the discussion, I address two points. First, protecting against wrongful convictions can create tradeoffs. If poorly crafted, a reform measure might not only prevent convicting innocent persons but also guilty persons, allowing dangerous criminals to avoid incarceration and continue to victimize innocent persons. From a public policy perspective, these tradeoffs create concern that reform measures may be cures worse than the disease.

With this caution in mind, I offer a second point: that it is possible to craft reforms that help to protect the innocent without allowing the escape of the guilty. A common theme underlying many of these proposals is that they reorient the criminal justice system away from adjudicating procedural issues and toward considering substantive issues - i.e., issues of guilt or innocence. The truly innocent will benefit in a system that values substance over procedure. We ought to give serious consideration to measures that move the system in that direction.

\section{Comparing and Quantifying the Risk of Wrongful Conviction to the Risk of Victimization}

\section{Two Kinds of Tragedies}

In considering the issue of wrongful convictions, some broader perspective is useful. To be sure, the conviction of even a single factually-innocent person is a tragedy. A grave and serious injustice has been done whenever the criminal justice system wrongfully convicts and

\footnotetext{
${ }^{1}$ Ronald N. Boyce Presidential Professor of Criminal Law, S.J. Quinney College of Law at the University of Utah. I appreciate the helpful comments of participants in the Symposium on Wrongful Convictions and the DNA Revolution: Twenty-Five Years of Freeing the Innocent at Northeastern University School of Law and Ron Allen, Patricia Cassell, Sam Gross, Josh Marquis, Daniel Medwed, and Erin Riley. This research was made possible in part through generous support from the Albert and Elaine Borchard Fund for Faculty Excellence.
} 
imprisons someone for a crime he has not committed. ${ }^{2}$ But, sadly, this is not the only kind of tragedy that the criminal justice system must be concerned about. ${ }^{3}$ A properly-functioning criminal justice system has to consider not only the suffering of those who have been wrongfully convicted, but also those who have become (or will become) the victims of crimes.

Violent crime victims and their families also suffer almost unimaginable emotional and physical pain — suffering that is often aggravated when the victim learns that the crime could have been prevented through a more effective criminal justice system. I will resist the temptation to appeal to the reader's emotions by recounting the specific details of what happened to them. The interested reader can easily find such unhappy details elsewhere. ${ }^{4}$ And these kinds of tragedies occur frequently. As Josh Marquis has observed, "[t]he justice system is far from perfect and has made many mistakes, mostly in favor of the accused. Hundreds, if not thousands, have died or lost their livelihood through embezzlement or rape because the American justice system failed to incarcerate people who were guilty by any definition.”5

How to assess these competing risks is exceedingly complex. Fortunately other thoughtful observers have already done important spadework on this issue. An extremely helpful discussion of the convicting-the-guilty-while-sparing-the-innocent tradeoff is found in Professor Ronald J. Allen and Investigator Larry Laudan's article Deadly Dilemmas. ${ }^{6}$ They explain that "[w]hile the prospect of convicting or executing a truly innocent person is horrifying, this type of mistake occurs within a highly complicated matrix of relationships where other equally horrifying mistakes go unnoticed in the conventional discourse."7 Allen and Laudan recognize that some public policy reform measures that reduce the risk of convicting an innocent person may simultaneously increase the risk that a guilty criminal will escape conviction and go on to

2 Like other authors in this book, I focus on so-called "wrong man" cases - i.e., cases of the "factually innocent" or "actually innocent" persons being wrongfully convicted. See Paul G. Cassell, The Guilty and the "Innocent:" An Examination of Alleged Cases of Wrongful Conviction from False Confessions, 22 HARV. J.L. \& PUB. POL'Y 523, 535 (1999). See also Michael L. Radelet, How DNA Has Changed Contemporary Death Penalty Debates, infra (discussing conceptual issues surrounding innocence); Josh Marquis, The Myth of Innocence, 95 J. CRIM. L. \& CriminolOGY 500, 508-09 (2005); Keith A. Findley, Defining Innocence, 74 AlB. L. REV. 1157 (2010).

3 See Paul G. Cassell, Freeing the Guilty Without Protecting the Innocent: Some Skeptical Observations on Proposed New “Innocence” Procedures, 56 N.Y. L. ScH. L. REV. 1063 (2011).

4 See, e.g., Paul G. Cassell, In Defense of Victim Impact Statements, 6 OHIO ST. J. CRIM. L. 611, 629-30 (2009) (collecting citations to examples of victim impact statements).

${ }^{5}$ Marquis, supra note 2, at 517-18.

${ }^{6}$ Ronald J. Allen \& Larry Laudan, Deadly Dilemmas, 41 TeXAS TeCh. L. ReV. 65 (2008). See also Larry Laudan \& Ronald J. Allen, Deadly Dilemmas II: Bail and Crime, 85 ChI.-KenT L. Rev. 23 (2010); Ronald J. Allen \& Larry Laudan, Deadly Dilemmas III: Some Kind Words for Preventive Detention, 101 J. CRIM. L. \& CRIMINOLOgy 781 (2011).

7 Allen \& Laudan, Deadly Dilemmas, supra note 6, at 68. 
commit additional violent crimes.

I will join Allen and Laudan in focusing on this possible tradeoff_-specifically, the risk that putting in place measures to protect against convicting innocent persons will allow guilty criminals to escape conviction. And I will likewise join them in narrowing the focus to a particular risk when the guilty are not convicted-specifically, the risk that an unconvicted criminal will go on to commit additional violent crimes (conventionally defined in the FBI's annual crime reports as murder, rape, robbery, and aggravated assault). Allen and Laudan have even attempted a tentative quantification of the precise tradeoff that exists in the current structure of our criminal justice system. Rather than try to reinvent the wheel here on quantitative assessments of the tradeoff, I want to simply take the Allen and Laudan calculation as accurate. In a separate article, I explore their numbers at greater length. ${ }^{8}$

Allen and Laudan concretely calculated comparative risks of a person being wrongfully convicted of a violent crime and being the victim of a serious crime. They derive an estimated lifetime risk of being wrongfully convicted for a serious crime ${ }^{9}$ of about $0.06 \%$ (6 out of 10,000). They then compare this figure to the lifetime risk of a person being the victim of a violent crime - a risk of about $83 \%$ (or, for comparison, 8300 out of 10,000). Based on these figures, Allen and Laudan conclude that "we can say with considerable confidence that the [lifetime] risk of being the victim of a serious crime in the United States is significantly more than 300 times greater than the lifetime risk of being falsely convicted of a serious crime.”10

\section{How to Think About Tradeoffs}

What, then, to make of these estimated, and obviously very tentative, risk ratios? Of course, one possible response is to attack the figures that Allen and Laudan derive. Professor D. Michael Risinger, for example, has written a lengthy and interesting critique of the Allen and Laudan calculation ${ }^{11}$ _a critique that I discuss at greater length elsewhere. ${ }^{12}$ The Allen and

\footnotetext{
8 See Paul G. Cassell, Comparing the Risk of Wrongful Conviction for a Violent Crime with the Risk of Being the Victim of a Violent Crime (manuscript on file with author).

${ }^{9}$ Their calculation refers to rape specifically, but it appears to be generalizable to other serious crimes as well. See id. at 80 n. 81.

${ }^{10}$ Id.at 79-80.

${ }^{11}$ D. Michael Risinger, Essay: Tragic Consequences of Deadly Dilemmas: A Response to Allen and Laudan, 40 SETON HALL L. REV. 991 (2010).

12 See Cassell, supra note 8.
} 
Laudan risk ratio does not rest on definitive numbers. Instead, as Professor Marvin Zalman has helpfully suggested, these kinds of calculations are estimates-perhaps akin to a National Intelligence Estimate that is provided in a national security context. ${ }^{13}$ But even assuming that the criminal justice system suffers a much higher rate of erroneous conviction than Allen and Laudan suggest, it is clear that the average person stands a vastly higher chance-by many multiples — of being a victim of violence than a casualty of a wrongful conviction. What I want to do here is assume that their calculation is roughly correct and tease out the implications.

Based on their risk ratio, Allen and Laudan contend that "insisting that we spare no efforts to reduce the risk of false conviction-even if the necessary measures significantly increase the risk of being a crime victim-is irrational.” ${ }^{14}$ In response, Risinger contends that the risk ratio of being a violent crime victim to being wrongfully convicted of a violent crime “does not make much difference” because "some such substantially higher risk must always attach to the risk of being a victim over the risk of being a convicted innocent simply as an inevitability of any likely set of social arrangements in the real world.”15

If I am reading Risinger correctly, I disagree with his position. The ratio victims to wrongfully conviction will always be (and should always be) greater than one. But surely it makes some difference in assessing proposed reform measures whether the ratio is in the neighborhood of, let's say, 2:1 or 300:1 (as Allen and Laudan suggested) or even more. Where the debate in this country is over what set of "social arrangements"-i.e., what sorts of innocence-protecting procedures ought to be place in criminal justice system-the size of these potential tradeoffs matter. Indeed, Risinger himself does not appear to hold rigidly to his position. In the penultimate sentence of his article, he makes a strong plea for adopting reforms that "help significant numbers of innocent convicted innocents without seriously impacting the rate of true convictions." 16 Of course, making assessments about what are "significant” numbers of innocent persons and whether an impact on the true conviction rate is "serious" requires some consideration of the magnitude of the numbers involved.

Risinger stands on much stronger ground in explaining that reform measures for addressing wrongful convictions can be divided into two categories with different moral

\footnotetext{
13 Marvin Zalman, Qualitatively Estimating the Incidence of Wrongful Convictions, 48 CRIM. L. BULL. 226,231 (2012).

14 Allen \& Laudan, supra note 6, at 80.

${ }^{15}$ Risinger, supra note 11 , at 1016-17.

${ }^{16}$ Id. at 1019.
} 
implications: Some reforms improve the diagnosticity of the system and thereby reduce the incidence of both wrongful convictions and wrongful acquittals or constitute reforms that protect the innocent with no reduction in convictions of the guilty-reforms that should be relatively uncontroversial. Other reforms, however, increase the protections for the innocent at the expense of freeing more guilty persons-reforms that are more controversial precisely because of the tradeoff involved. ${ }^{17}$

The possibility that the most significant reforms will produce significant tradeoffs cannot be overlooked. One concrete illustration (provided by Allen and Laudan) is reforms regarding eyewitness identification. This appears to be one the most common causes of wrongful convictions. ${ }^{18}$ And yet many of the reform measures to address the problem appear to carry with them not only the prospect of avoiding misidentifications but also the possibility of discouraging accurate identifications. ${ }^{19}$ More broadly, as Professor Chris Slobogin has noted, “[m]ost reformist energy has understandably been focused on reducing wrongful convictions, through improved interrogation techniques, and identification procedures, defense involvement in the investigative process, and the like. Most of these reforms, however, could also increase wrongful acquittals . . .."20

Fully assessing the tradeoffs involved between what might be called rightful convictions and wrongful acquittals is an issue that dates back at least to Blackstone's suggestion that it is "[b]etter that ten guilty persons escape than that one innocent suffer." 21 A strong argument can be made (and has been made by Risinger, among others in that long tradition) that the State bears

${ }^{17}$ Id. at 1001.

18 The National Registry of Exonerations listed "mistaken witness ID" as the third leading cause of wrongful convictions, trailing only perjury/false accusation and official misconduct. National Registry of Exonerations, \% Exonerations by Contributing Factor, available https://www.law.umich.edu/special/exoneration/Pages/ExonerationsContribFactorsByCrime.aspx\#.

19 See Steven E. Clark, Blackstone and the Balance of Eyewitness Identification Evidence, 74 AlBANY L. REv. 101 (2011); see also Laurie N. Feldman, The Unreliable Case Against the Reliability of Eyewitness Identifications: A Response to Judge Alex Kozinski, _ QUINNIPIAC L. REV. _ (forthcoming), available at

http://papers.ssrn.com/sol3/papers.cfm?abstract_id=2684478. For a helpful summary of the reform possibilities in this area, see Brandon L. Garrett, Conviction the InNocent: Where Criminal Prosecutions Go Wrong 248-52 (2011).

${ }^{20}$ Chris Slobogin, Lessons from Inquisitorialism, 87 S. CAL. L. REV. 699, 704 (2014); see also D. Michael Risinger \& Lesley C. Risinger, Innocence Is Different: Taking Innocence into Account in Reforming Criminal Procedure, 56 N.Y.L. SCH. L. REV. 869, 898 (2012) (problems with eyewitness misidentification are hard to be address because they are "inherent in the phenomenon").

214 William Blackstone, Commentaries *358; see also Alexander Volokh, $N$ Guilty Men, 146 U. PA. L. ReV. 173 (1997). For a recent and comprehensive effort to lay out a theoretical framework for evaluating such tradeoffs, see Daniel Epps, The Consequence of Error in Criminal Justice, 128 HARV. L. REV. 1065 (2015). 
a "special responsibility to insure that innocents that it sweeps up in carrying out its crimecontrol functions are not convicted”- a responsibility that exceeds its obligations to prevent crime that is the "free-will-based choice" of a criminal. ${ }^{22}$

And it also seems likely that the societal costs of a single wrongful felony conviction are higher than the societal costs of a single violent crime (setting aside the special case of homicide). One way to quantify this point would be compare jury verdicts (or civil settlements) in cases of wrongful conviction with jury verdicts in cases of criminal assaults. A recent study, for example estimated the total tangible plus intangible pre-offense cost for different crimes (in 2008 dollars). The study concluded that the loss per crime victimization can be quantified as $\$ 8,982,907$ for a murder, $\$ 240,776$ for a rape/sexual assault, $\$ 107,020$ for an aggravated assault, and $\$ 42,310$ for a robbery. ${ }^{23}$ Comparable data could be collected for wrongful conviction cases, where substantial civil judgments (some of them larger than the numbers just cited ${ }^{24}$ ) have been entered in favor of those wrongfully convicted. A further quantitative refinement of the tradeoffs discussed above would then be possible. ${ }^{25}$

But adding to the complexities, there is a good possibility that releasing a guilty criminal produces not a single violent crime, but rather multiple crimes. Criminals have high rates of recidivism and, if not incarcerated, may commit dozens of crimes before caught. ${ }^{26}$ Laudan, for example, has estimated that "every false acquittal enables more than thirty-six crimes (including on average seven violent ones) during the time when, but for the false acquittal, the defendant would have been incapacitated."27

\footnotetext{
22 Risinger, supra note 11, at 1020. See also Allen \& Laudan, supra note 6, at 81-84 (discussing arguments by Ronald Dworkin and Immanuel Kant); Epps, supra note 21, at 1133-35.

${ }^{23}$ Kathryn E. McCollister et al., The Cost of Crime to Society: New Crime-Specific Estimates for Policy and Program Evaluation, 108 DRUg \& Alcohol DePENDENCE 98, 105 tbl. 5 (2010); see also Ted R. Miller, Marc A. Cohen \& Brian Wiersema, Nat'l Inst. of Justice, Victim Costs AND CONSEQUENCES: A NEw LOOK 9 tbl. 2 (1996) (using older data to conclude that loss per crime victimization can be quantified as $\$ 2,940,000$ for a murder, $\$ 87,000$ for a sexual assault, and $\$ 19,000$ for a robbery with injury). Cf. David A. Anderson, The Cost of Crime, 7 FOUNDATIONS \& TRENDS IN MICROECONOMICS 209 (2012) (estimating total cost of crime in the U.S. at \$3.2 trillion, more than total health care costs). Similar figures from those quoted in the text come from the RAND Center on Quality Policing, which calculates a cost per murder of $\$ 8,649,216$, per rape of $\$ 217,866$, per aggravated assault of $\$ 87,238$, and per robbery of $\$ 67,277$. Paul Heaton, Hidden in Plain Sight: What Cost-of-Crime Research Can Tell Us About Investing in Police, available at http://www.rand.org/content/dam/rand/pubs/occasional_papers/2010/RAND_OP279.pdf (2010).

24 See, e.g., Limone et al. v, United States, No. 02-cv-10890-NG (D. Mass. 2007) (\$101.7 million judgment).

${ }^{25}$ Cf. Paul G. Cassell, Too Severe?: A Defense of the Federal Sentencing Guidelines (and a Critique of the Federal Mandatory Minimums), 56 STAN. L. REV. 1017, 1037-41 (2004) (discussing cost-benefit analysis in federal sentencing based on victimization figures).

${ }^{26}$ See JAMES Q. Wilson, Thinking ABout CRIME 145-58 (1983).

${ }^{27}$ Larry Laudan, The Rules of Trial, Political Morality, and the Costs of Error: Or, Is Proof Beyond a Reasonable
} 
One other qualitative factor might also need to be entered into the calculation: The general moral culpability of those who have been wrongfully convicted versus those who have been victims of crime. The reader of this book, after seeing numerous accounts of wrongful convictions, may wonder what he or she can do to avoid such a fate. While the other Chapters in this book do not discuss the answer to this question in detail, it seems likely that the best single answer is a simple one: Don't commit a serious crime, particularly a crime of violence. While the innocence literature does not highlight the fact, it appears that many of those wrongfully convicted were convicted because they had committed other crimes-either at the time of the crime for which they were wrongfully convicted or earlier. For example, prior arrests can produce police photographs that can end up in a photospread to be misidentified. Or prior crimes may arouse the suspicion of police detectives.

One prominent illustration of how the wrongfully convicted may have some moral culpability is Anthony Porter, who was convicted of committing a drug-related homicide. But it was apparently difficult for him to present a defense to that charge, because he may have been committing an armed robbery in the same park at the same time. He ran from the park, gun in hand, in full view of witnesses. Porter then denied not only the murder, but also being in the park — a lie he maintained until after his convictions were affirmed. ${ }^{28}$

The prevalence of criminal activity by those wrongfully convicted is suggested by a case I recently worked on involving an alleged wrongful conviction of Robert Wilcoxson. ${ }^{29}$ The North Carolina Innocence Inquiry Commission found Wilcoxson to be innocent of a drug-related murder. But it appears that one reason he fell under suspicion is that (by his own admission) at the time of the murder he was an armed cocaine dealer making tens of thousands of dollars from

\footnotetext{
Doubt Doing More Harm than Good?, in 1 Oxford STUDIES IN PHILOSOPHY OF LAW 195, 202 (Leslie Green \& Brian Leiter eds., 2011). But cf. Epps, supra note 21, at 1090-91 (critiquing this estimate).

28 See Marquis, supra note 2, at 517. Whether Porter was in fact innocent has been called into doubt by a new documentary movie, A Murder in the Park. The documentary investigates the fact that Porter was released after a Medill Innocence Project investigation obtained a confession from Alstory Simon to the murder-a confession that led to Porter's exoneration and Simon's incarceration. But later Simon's murder conviction was overturned, in part because of the Innocence Project's coercive investigative tactics had tainted the case against Simon. See Jim Stingl, Duped by Medill Innocence Project, Milwaukee Man Now Free, MiLWAUKEE JouRnAL-SENTINEL, available at http://www.jsonline.com/news/milwaukee/duped-by-innocence-project-milwaukee-man-now-free-b99386015z1281852841.html.

29 Disclosure: I served as an expert witness for law enforcement officers involved in the civil litigation that resulted from this case.
} 
his crimes. ${ }^{30}$ Four other adults also fell under suspicion and were also convicted, wrongfully they have argued. Still, it appears that they may have all have been involved in doing a series of armed robberies at around the same time. ${ }^{31}$ Thus, in this one case, possibly involving multiple wrongful convictions, it appears that all five of the allegedly wrongfully convicted participants were involved in other dangerous crimes apart from the murder for which they were convicted, which made it harder for them to convince authorities of their innocence.

The point here is not to blame those wrongfully convicted for their plight. The more limited point is that, when assessing the priority to be given to competing claims between those wrongfully convicted and those who are past (or prospective) crime victims, in the aggregate the victims may have a far stronger claim. Some support for this position comes from a study reporting that, for homicide and assault cases, the majority of the victims had no prior arrest record, while the majority of the offenders did. ${ }^{32}$

A related point can be made about the wrongfully convicted who have pled guilty. Unless the defendant has entered an Alford plea (refusing to plead guilty but preserving his position of innocence), he has almost certainly committed perjury before the Court in entering his plea. Consider, for example, Robert Wilcoxson and Kenneth Kagonyera. ${ }^{33}$ At their guilty plea hearings, both swore under oath that they were guilty, that they were satisfied with defense counsel, and that the other requisites for a knowing and voluntary guilty plea existed. So far as the court records reveal, they also made no effort to enter an Alford plea. In addition, following Kagonyera's decision to plead guilty, he met with the prosecutor and, in the presence of defense counsel made a very detailed statement about his involvement in the murder, implicating five other people. ${ }^{34}$ Kagonyera made these statements at his own initiative in an effort to convince the District Attorney that he could provide useful information by testifying against his codefendants. ${ }^{35}$

\footnotetext{
${ }^{30}$ Deposition of Robert Wilcoxson, Wilcoxson v. Buncombe County et al., No. 1:13-cv-00224-MR-DLH (W.D>N.C. 2014).

31 Testimony of Damian Mills to North Carolina Innocence Inquiry Commission, Dec. 18, 2013, at 481-82 (saying that he had been doing a series of breaking-and-enterings with Kagonyera, Williams, Isbell, and Brewton).

32 See Arnite A. Varnedo, Characteristics of Offenders Arrested for Aggravated Assault, A Thesis Submitted to Dep’t of Criminal Justice Administration, Atlanta Univ., at 8-9 (May 1987).

33 See North Carolina Innocence Inquiry Commission, State $v$. Kagonyera/Wilcoxson, available at http://www.innocencecommission-nc.gov/kagonyera.html.

34 Memo. from Investigator Raymond to D.A. Moore regarding statement of Kenneth Kagonyera (Nov. 30, 2001) (memorializing statements made on Nov. 29, 2001).

${ }^{35}$ Kagonyera Dep. (1/9/15) at 134-35 (admitting this fact).
} 
To be clear, if Kagonyera and Wilcoxson were in fact innocent, ${ }^{36}$ their guilty pleas were plainly wrongful convictions. And no doubt, their pleas resulted from a plea bargaining process that can be coercive and place considerable pressure on even innocent persons to plead guiltymaking the choice of an innocent person to plead guilty in some sense rational. ${ }^{37}$ But particularly where defendants (like Kagonyera and Wilcoxson) have made no effort to enter Alford pleas, ${ }^{38}$ a decision to mislead the Court and enter a guilty plea produces a wrongful conviction that is, at least to some extent, the result of illegal choices on their part and presumably entitled to somewhat less weight in social harm calculus. ${ }^{39}$

I would like to see more discussion of and data on these questions, and particularly the extent to which those wrongfully convicted had prior criminal records or were participating in crimes at the time of the offense for which they were wrongfully convicted. (Similar data on victims would be interesting too.) But the critical point here is that unraveling such competing claims to priority in reform promises to be very difficult.

In this short Chapter, rather than embark on what would be a complicated effort to precisely quantify tradeoffs for particular reforms, I would like to search for reforms that help protect the innocent without freeing the guilty ${ }^{40}$-reforms that ought to be relatively uncontroversial, at least for those (including many of the authors in this book) who prioritize innocence issues over other values in the criminal justice system. ${ }^{41}$ I agree with those who argue that the risk our criminal justice system poses to the innocent is not trivial. ${ }^{42}$ But as the above quantification suggests, neither is the risk to crime victims, who bear the brunt of any failures of the system to apprehend or prosecute dangerous criminals. It is against that backdrop that I turn to possible reforms that try to carefully attend to both sides of the equation. ${ }^{43}$

36 The North Carolina Innocence Inquiry Commission has found both men to be factually innocent.

37 Compare Josh Bowers, Punishing the Innocent, 156 U. PA. L. REV. 1117 (2008) with Stephanos Bibas, Exacerbating Injustice, 157 U. PA. L. REV. PENNuMBRA 53, 54 (2008) (responding to Bowers’ article)

38 Currently about 47 states, the District of Columbia, and the federal system allow Alford pleas. See Stephanos Bibas, Harmonizing Substantive-Criminal-Law Values and Criminal Procedure: The Case of Alford and Nolo Contendere Pleas, 88 CORNELL L. REV. 1351, 1372-73 n.52 (2003).

39 It is also possible that they choose to plead guilty to the murder because they were guilty of other serious, violent crimes. See supra notes 26-27 and accompanying text.

${ }^{40} \mathrm{I}$ also search for reforms that do not reduce punishment for the guilty. Cf. Erik Luna \& Paul G. Cassell, Mandatory Minimalism, 32 CARDOZO L. REV. 1 (2010) (arguing for reduction in mandatory minimum sentences, a reform that might not only shorten sentences for the guilty but also reduce pressure on innocent defendants to plead). 41 See, e.g., Daniel S. Medwed, Innocentrism, 2008 U. ILL. L. REV. 1549. See generally DANIEL S. MEDWED, PROSECUTION COMPLEX: AMERICA’s RACE TO CONVICT AND ITS IMPACT ON THE INNOCENT (2012).

42 Risinger, supra note 11 , at 999.

43 See, e.g., Keith A. Findley, Toward a New Paradigm of Criminal Justice: How the Innocence Movement Merges 


\section{Protecting the Innocent While Simultaneously Convicting the Guilty}

In light of the risk of potential tradeoffs between convicting the guilty while protecting the innocent, the reforms that are most likely to be justified on cost-benefit analysis will be those that do not present any significant risk of increasing crime victimization rates. I have previously offered some thoughts on how this might be done. ${ }^{44}$ This short section highlights a few promising possibilities.

\section{More Research on the Frequency and Causes of Wrongful Convictions}

At the top of my list of measures to address the problem of wrongful convictions of the innocent is further research on the extent and causes of the problem. ${ }^{45}$ In the previous section, I noted the Allen and Laudan calculations, which rested on very thin data. ${ }^{46}$ For public policy purposes, we need more information-information about, for example, wrongful convictions through guilty pleas (a key part of the Allen and Laudan estimate) and solid information about the incidence of wrongful convictions outside the areas of homicide and rape.

The additional research needs to focus on the frequency of false confessions. Professor Samuel Gross has aptly observed that "[t]he most important question about false convictions is also the most basic: How frequently are innocent people convicted of crimes?" ${ }^{47}$ To be sure, on the twenty-fifth anniversary of the first DNA exonerations, we now have far more information about wrongful convictions than in the past. But even disregarding the questions about how "innocence" is determined in some of this research, ${ }^{48}$ a more fundamental problem is the fact

Crime Control and Due Process, 41 TEX. TECH. L. REV. 133, 134 (2008) (arguing that the goals of convicting the guilty and protecting the innocent are not mutually exclusive).

${ }^{44}$ See generally Cassell, supra note 3.

${ }^{45}$ Others have made similar pleas. See Morris B. Hoffman, The Myth of Factual Innocence, 82 CHI.-Kent L. REV. 663, 689 (2007); see also Marvin Zalman \& Julia Carrano, Sustainability of Innocence Reform, 77 ALB. L. REV. 955, 983-993 (2014) (outlining research agenda for innocence issues).

${ }^{46}$ See Samuel R. Gross et al., Rate of False Conviction of Criminal Defendants Who Are Sentenced to Death, 111 PNAS 7231 (May 20, 2014) (noting Risinger study, relied upon by Allen and Laudan for error rate, ultimately is based on only 11 cases of wrongful conviction).

47 Samuel Gross, Convicting the Innocent, 4 ANN. REV. L. Soc. SCI. 173, 176 (2008).

${ }^{48}$ Compare Hugo Adam Bedau \& Michael L. Radelet, Miscarriages of Justice in Potentially Capital Cases, 40 STAN. L. REV. 21, 72-75 (1987) (presenting cases of alleged execution of the innocent), with Stephen J. Markman \& Paul G. Cassell, Protecting the Innocent: A Response to the Bedau-Radelet Study, 41 STAN. L. ReV. 121 (1988) (questioning the accuracy of the determinations of "innocence”); compare also Richard A. Leo \& Richard J. Ofshe, 
that a collection of alleged miscarriages based on DNA or any other factor may not be representative of the processing of cases in the American criminal justice system. ${ }^{49}$

To avoid this problem, researchers could take a random sample of a large number of felony criminal violent crime cases (1,000 seems like a good number) and then track them through the system to see what happens. ${ }^{50}$ While it might not be possible to follow all 1,000 cases carefully, it would seem likely that the cases where a defendant might plausibly be innocent would shrink the numbers down fairly rapidly. Researchers could focus on this subset of cases and try to come up with an initial, plausible number of cases in which a wrongful conviction was even a possibility, and then perhaps press even further to try and get to the bedrock truth in this subset of cases. This methodology has already been employed in other countries in the false confessions area. ${ }^{51}$ It should be tried on the broader subject of wrongful convictions. Research of this type might be very valuable for revealing both the scope of the wrongful conviction problem and particular areas where wrongful convictions are prevalent. This would permit a targeted response to the problem, perhaps more narrowly addressing the risk to the innocent without freeing the guilty. ${ }^{52}$

\section{Refocus Post-Conviction Relief on Claims of Factual Innocence}

One of the great problems for the innocence movement is trying to find the needles in a large haystack - that is, trying to identify innocent persons in a criminal justice system that processes mostly guilty defendants. Some commentators have made a frontal assault on this

The Consequences of False Confessions: Deprivations of Liberty and Miscarriages of Justice in the Age of Psychological Interrogation, 88 J. CRIM. L. \& CRIMINOLOGY 429 (1998) (presenting cases of alleged wrongful convictions from false confessions), with Paul G. Cassell, The Guilty and the "Innocent": An Examination of Alleged Cases of Wrongful Convictions from False Confessions, 1999 HARV. J.L. \& PUB. POL'Y 523 (1999) (questioning the accuracy of the determinations of "innocence").

${ }^{49}$ See George C. Thomas III, Prosecutors: The Thin Last Line Protecting the Innocent, infra; Samuel R. Gross \& Barbara O’Brien, Frequency and Predictors of False Conviction: Why We Know So Little, and New Data on Capital Cases, 5 J. EMPIRICAL LEGAL STUD. 927 (2008).

${ }^{50}$ Others have proposed creating a commission to study cases of proven wrongful convictions. See, e.g., Keith A. Findley, Learning from Our Mistakes: A Criminal Justice Commission to Study Wrongful Convictions, 38 CAL. W. L. REV. 333 (2002). My proposal is slightly different because I propose to conduct research to expand our knowledge about a random sample of wrongful convictions, rather than simply study the nonrandom sample of wrongful convictions that have already come to light.

${ }^{51}$ See, e.g., Gisli H. Gudjonsson \& Jon F. Sigurdsson, How Frequently Do False Confessions Occur?: An Empirical Study Among Prison Inmates, 1 PsyCHOL. CRIM \& L. 21, 25 (1994).

${ }^{52}$ For example, I have previously proposed that we should pay particular attention to issues involving alleged false confessions by the mentally retarded, rather than overgeneralizing the problem and proceeding on the assumption that false confessions are a routine product of police interrogation of those with normal mental faculties. See Cassell, supra note 2, at 580-87. 
problem by proposing that we limit access to some forms of judicial review to those who are making claims of actual innocence. For example, two distinguished legal scholars-Joseph Hoffmann and Nancy King-proposed that federal habeas corpus review of noncapital state court convictions and sentences should, with narrow exceptions, be abolished except for those who couple a constitutional claim with "clear and convincing proof of actual innocence.”53 Relying on a comprehensive study of federal habeas corpus filings, ${ }^{54}$ they found that only seven of the 2,384 noncapital habeas filings in the study (0.29\%) resulted in a grant of habeas relief, and one of those seven was later reversed on appeal. ${ }^{55}$ Hoffmann and King argued that habeas review of such claims "currently squanders resources while failing to remedy defense-attorney deficiencies. Those resources should be redeployed where they have a more meaningful chance of preventing the deficiencies in the first place.” 56 They propose moving resources to indigent defense representation instead of largely pointless habeas litigation.

Hoffmann and King's proposal is similar to others that have tried to focus habeas corpus on protecting the innocent. Most famously, Judge Henry Friendly argued that federal habeas relief for most constitutional errors should be conditioned on a showing of innocence. ${ }^{57}$ Interestingly, he also proposed that a sufficient demonstration of innocence should itself be a basis for habeas relief, ${ }^{58}$ an issue that has bedeviled the Supreme Court in recent years. ${ }^{59}$ Similarly, Professors John Jeffries, Jr. and William Stuntz have suggested allowing defaulted federal claims to be raised in federal habeas where those claims raise a reasonable probability that the defaulted claims resulted in an erroneous conviction. ${ }^{60}$ Professor Samuel Gross has

\footnotetext{
${ }^{53}$ Joseph L. Hoffmann \& Nancy J. King, Rethinking the Federal Role in State Criminal Justice, 84 N.Y.U. L. REV. 791, 820 (2009).

54 Nancy J. King et al., Final Technical Report: Habeas Litigation in U.S. District Courts (2007), available at http://www.ncjrs.gov/pdffiles1/nij/grants/219559.pdf.

${ }^{55} \mathrm{Id}$. at $52,58,115-16$.

${ }^{56}$ Hoffman \& King, supra note 53, at 823.

${ }^{57}$ See Henry J. Friendly, Is Innocence Irrelevant? Collateral Attack on Criminal Judgments, 38 U. CHI L. REV. 143 (1970).

${ }^{58} \mathrm{Id}$. at 167.

${ }^{59}$ See Joshua M. Lott, The End of Innocence? Federal Habeas Corpus Law After In re Davis, 27 GA. ST. U. L. REV. 443 (2011). The Supreme Court has stated that "[t]he existence merely of newly discovered evidence relevant to the guilt of a state prisoner is not a ground for relief on federal habeas corpus." Herrera v. Collins, 506 U.S. 390, 398 (1993) (quoting Townsend v. Sain, 372 U.S. 293, 317 (1963)). Nonetheless, there has been enough uncertainty about that statement that more than one hundred freestanding innocence claims have since been filed in federal habeas courts. See Nicholas Berg, Turning a Blind Eye to Innocence: The Legacy of Herrera v. Collins, 42 AM. CRIM. L. REV. 121, 131 (2005).

60 John C. Jeffries, Jr. \& William J. Stuntz, Ineffective Assistance and Procedural Default in Federal Habeas Corpus, 57 U. CHI. L. REV. 679 (1990).
} 
argued for giving defendant claiming innocence the option for an "investigative trial," in which the defendant would be able to argue his innocence, provided he waived important rights - in exchange, the defendant (if convicted) would be given greater freedom to raise post-conviction claims of innocence. ${ }^{61}$ And most recently, in this book, Professor Stephanie Hartung has argued for a post-conviction "innocence track" in federal habeas, under which any prisoner who establishes innocence by a preponderance of the evidence would be entitled to a blanket exemption from procedural bars. ${ }^{62}$

One of the interesting things about post-conviction review is that, by definition, it cannot interfere with the process of convicting the guilty at trial. Accordingly, post-conviction review offers a particularly promising approach for escaping the tradeoffs highlighted earlier. ${ }^{63}$

One proposal worth serious exploration combines aspects of the Hoffmann and King proposal, along with Judge Friendly's insight that federal habeas should focus on innocence and Professor Hartung's idea for an innocence track. We could restrict federal habeas to those who have a colorable claim of factual innocence. Those prisoners could then be required to establish factual innocence by a preponderance of the evidence and, if they did so, they would have a blanket exemption from any procedural bars to raising claims for relief in federal court. ${ }^{64}$ I would also add to Hartung's innocence track the idea that if a prisoner who had proven he was innocent did not receive federal habeas relief, the federal courts could at least remand the case back to the prisoner's State Supreme Court for further inquiry as to whether state relief might be available.

Professor Hartung (and others) may wonder about why the innocence track needs to be coupled with the abolition of federal habeas for those who are raising claims unrelated to innocence. The answer is straightforward: time, energy, and resources are limited. Given Hoffmann and King's finding that federal habeas relief for procedural violations is essentially an impossibility, it make no sense to allow those claims to continue to be pressed before federal courts. Restructuring federal habeas so that it only concerns prisoners alleging factual innocence would help federal courts re-conceptualize their mission to the benefit of wrongfully convicted

\footnotetext{
${ }^{61}$ Samuel R. Gross, Pretrial Incentives, Post-Conviction Review, and Sorting Criminal Prosecutions by Guilt or Innocence, 56 N.Y.L. SCH. L. REV. 1009 (2011).

${ }^{62}$ Stephanie Roberts Hartung, Post-Conviction Procedure: The Next Frontier in Innocence Reform, infra.

63 A similar point can be made in support of Professor Warden's proposal to give close attention to post-conviction recantation by trial witnesses. See Rob Warden, Reacting to Recantations, infra.

${ }^{64}$ For an interesting effort along these lines in the area of direct appeals, see Helen A. Anderson, Revising Harmless Error: Making Innocence Relevant to Direct Appeals, 17 TEX. WESLEYAN L. REV. 391 (2011).
} 
prisoners-precisely the sort of change that helps the innocent without freeing the guilty. It seems almost irrefutable that the innocent will benefit from a system concentrating on themthat is, that we can find needles more effectively in smaller haystacks.

\section{Increasing Resources for Indigent Defense Counsel and Prosecutors to Focus on Issues Relating to Actual Innocence}

On the issue of wrongful convictions, the elephant in the room is little discussed but obvious: money. The root cause of wrongful convictions is almost certainly insufficient resources devoted to the criminal justice system. Whatever individual causes might be pinpointed in particular cases, more resources would often have enabled defense counsel (or police and prosecuting agencies) to locate persuasive evidence of innocence. ${ }^{65}$ If this diagnosis is correct, then an important part of the true solution to the wrongful conviction problem may be devoting additional resources to the criminal justice system. ${ }^{66}$

Given the fiscal realities of the world we live in, however, it may be an academic proposal to call for significant new funding for defense attorneys, for example. ${ }^{67}$ At a macro level, the funds devoted to the criminal justice system are probably roughly fixed and not much is likely to change in the near term. ${ }^{68}$ What is needed, then, is to prioritize innocence over other criminal justice expenditures. Fortunately, for those who truly believe in "innocentrism," there are ways to do this—as I discuss in the next several sections.

\section{Abolishing the Fourth Amendment Exclusionary Rule, and Consequently Shifting Defense Resources Away from Litigating Purely Procedural Claims}

If we want the criminal justice system to prioritize the issue of innocence and devote more resources to it, then a good start would be to consider abolishing the Fourth Amendment exclusionary rule. Abolition of the rule and replacing it with a system of civil damage remedies

\footnotetext{
65 See Robert Gehrke, If Utah Doesn't Provide Better Legal Defense for the Poor, ACLU May File Lawsuit, SALT LAKE TRIB., Sept. 20, 2015, available at http://www.sltrib.com/news/2966774-155/if-utah-doesnt-provide-betterlegal (discussing case of wrongful conviction in Utah where overworked public defender was apparently unable to obtain alibi witnesses).

${ }^{66}$ See, e.g., Alexandra Natapoff, Negotiating Accuracy: DNA in the Age of Plea Bargaining, infra.

${ }^{67}$ See Mary Sue Backus \& Paul Marcus, The Right to Counsel in Criminal Cases, a National Crisis, 57 HASTINGS L.J. 1031, 1059 (2006); Paul Cassell \& Nancy Gertner, Public Defenders Fall to the Sequester, Wall ST. J., Aug. 20, 2013 (urging that federal public defender funds not be sequestered).

${ }^{68}$ See Erik Lillquist, Improving Accuracy in Criminal Cases, 41 U. RicH. L. ReV. 897 (2007) (noting a common assumption that there are fixed resources devoted to criminal justice).
} 
has been advocated by such distinguished legal figures as Chief Justice Warren Burger, ${ }^{69}$ Dallin Oaks, ${ }^{70}$ Akhil Amar, ${ }^{71}$ Bill Pizzi, ${ }^{72}$ and Paul Robinson. ${ }^{73}$ The classic argument for abolishing the exclusionary rule is that the rule sets criminals free because the constable has blundered. ${ }^{74}$ But there is a more subtle, and in many ways more pernicious, defect to the exclusionary rule. Under a regime that allows the "deliberate exclusion of truth from the fact-finding process," 75 defense efforts will move toward issues involving the validity of evidence collection rather than toward assessing the quality of the evidence itself. Professor William Stuntz perhaps most famously made this point in his writings, explaining how a system with limited resources that emphasizes procedure over substance will give short shrift to factual claims of innocence. ${ }^{76}$ Stuntz is cautious in his argument. As he explains, the current system does not simply involve a direct tradeoff, but rather "places substantial pressure on [defense] counsel to opt for the procedural claim rather than the (potential) substantive one."77 But Stuntz's bottom-line conclusion seems unassailable: there is some tradeoff in the current regime favoring procedural claims over substantive ones. ${ }^{78}$

In addition to these kinds of tradeoffs, the exclusionary rule creates a perverse screening at trial. ${ }^{79}$ Jurors deciding cases may believe that a weak prosecution case actually is the result of the exclusion of evidence. Because of facts such as these, it seems difficult to contest that “actually guilty defendants are most likely to benefit from the exclusionary rule.” 80

${ }^{69}$ See Stone v. Powell, 428 U.S. 465, 500-01 (1976) (Burger, C.J., concurring).

70 See Dallin H. Oaks, Studying the Exclusionary Rule in Search and Seizure, 37 U. CHI. L. REV. 665, 739-40 (1970).

${ }^{71}$ See AKhil Reed Amar, The Constitution AND Criminal Procedure 40-45 (1997).

72 See William T. Pizzi, Trials Without Truth: Why Our System of Criminal Trials Has Become an EXPENSIVE FAILURE AND WHAT WE NEED TO DO TO REBUILD IT (1999).

73 Paul H. Robinson \& Michael T. Cahill, Law Without Justice: Why Criminal LaW Doesn’t Give People WHAT THEY DESERVE (2006).

${ }^{74}$ People v. Defore, 150 N.E. 585, 587(N.Y.1926).

75 Stone v. Powell, 428 U.S. 465, 496 (Burger, C.J., concurring).

${ }^{76}$ William Stuntz, The Uneasy Relationship Between Criminal Procedure and Criminal Justice, 107 YALE L.J. 1, 37-40 (1997).

${ }^{77}$ Id. at 40.

78 Professor Robert Mosteller responded to Stuntz's argument by reporting his own experience that motions to suppress "posed only a minimal drain on defense resources.” Robert P. Mosteller, Protecting the Innocent: Part of the Solution for Inadequate Funding for Defenders, Not a Panacea for Targeting Justice, 75 Mo. L. REV. 931, 95556 (2010). But Mosteller concedes that his experience comes from a system in which motions to suppress were set on the eve of trial, thereby preventing most such motions from being litigated. Id. at 956. Such a system seems atypical to me. For example, in both the state and federal systems in Utah, motions to suppress are typically litigated well in advance of trial and thus often produce contested suppression hearings.

${ }^{79}$ Tonja Jacobi, The Law and Economics of the Exclusionary Rule, 87 NOTRE DAME L. REV. 585, 633 (2015).

80 Id. at 636. 
Given these tradeoffs, those with an innocentric view of the world should be the first to jump on the replace-the-exclusionary-rule-with-civil-damages bandwagon. Surely the experience of the rest of the world suggests that the exclusionary rule is not the only way to restrain police abuses. ${ }^{81}$ There is good reason to think that we can craft a damages regime for protecting Fourth Amendment rights that will fully preserve them, just as we rely on a damages regime to protect other civil liberties, such as our First Amendment rights. ${ }^{82}$

Once procedural issues regarding the legality of searches are diverted to the civil justice system, the criminal justice system would gain substantial new resources to devote to innocence issues. While the percentage of cases in which the exclusionary rule results in guilty criminals going free is disputed, ${ }^{83}$ it does not appear to be disputed that the exclusionary rule results in “tens of thousands of contested suppression motions each year." ${ }^{84}$ Instead of filing and litigating these motions that have nothing to do with innocence, defense counsel could turn their attention to substantive issues about who committed the crime. Prioritizing substantive issues of guilt and innocence over procedural issues of the reasonableness of searches is exactly the way the system should be structured-and a way the both increases the chance of convicting the guilty while reducing the chance of convicting the innocent.

\section{Replacing the Miranda Regime with the Videotaping of Custodial Interrogations}

The problem of procedure over substance is not confined solely to Fourth Amendment jurisprudence. The same flaw has developed in confession law. Here again, those who are most concerned about innocence should be skeptical of the law's current structure, which relies largely

\footnotetext{
81 See Roper v. Simmons, 543 U.S. 551, 624 (2005) (Scalia, J., dissenting) (noting that when adopted, the exclusionary rule was "unique to American jurisprudence" and that "a categorical exclusionary rule has been 'universally rejected' by other countries”); see also William T. Pizzi, The Need to Overrule Mapp v. Ohio, 82 U. CoLO. L. Rev. 679, 717-29 (2011) (discussing limited use of exclusionary remedies in Canada, New Zealand, England and Ireland).

82 See Akhil Amar, The Constitution And Criminal Proceddre 27-29 (1998) (explaining why the exclusionary rule is a bad way to deter police misconduct compared to a civil damages regime). $C f$. Yale Kamisar, Mapp v. Ohio 50 Years Later, NAT'L L.J., June 13, 2011, at 50 (arguing that critics of the exclusionary rule may not really want an effective alternative remedy because it would be just as burdensome on law enforcement).

${ }^{83}$ Compare United States v. Leon, 468 U.S. 897, 907 (1984) (arguing that the small percentage researchers deal with masks the large number of felons released from prison based in part on illegal searches and seizures), with id. at 950 (Brennan, J., dissenting) (arguing that only a very small percentage of all felony arrests are declined for prosecution on grounds of potential exclusionary rule problems).

${ }^{84}$ McDonald v. City of Chicago, 561 U.S. 742, 785 (2010) (quoting William Stuntz, The Virtues and Vices of the Exclusionary Rule, 20 HARV. J.L. \& PUB. POL’y 443, 444 (1997)).
} 
on Miranda warnings and waivers to protect against coercive interrogations. As a practical matter, this approach does little to help the innocent and prioritizes litigation about Miranda compliance over litigation about the accuracy of confessions. The result has been a regime that is not particularly well-suited to address “false confession” issues ${ }^{85}$-i.e., is not well-suited to protecting the innocent. Today Miranda "serves mainly to distract lawyers, scholars, and judges from considering the real problem of interrogation, which is how to convict the guilty while protecting the innocent." 86

The "central problem with Miranda is that it was not crafted specifically to prevent false confessions, but rather to regulate interrogations more generally." 87 The problem starts with the probability that innocent defendants are most likely to waive their Miranda protections. Innocent persons have nothing to hide from the police, and so they almost invariably waive their Miranda rights. ${ }^{88}$ Once they waive their rights, the Miranda procedures do little (if anything) to restrain police questioning techniques, a point that seems to be generally accepted. ${ }^{89}$

Miranda's procedural requirements, like those of the Fourth Amendment exclusionary rule, also shift defense attorney time and attention away from claims of innocence. The Miranda procedures have spawned considerable litigation about whether a suspect was in "custody," whether a suspect "waived" his rights, or whether a suspect "invoked" his right to counsel. ${ }^{90}$ These issues generally have little to do with the reliability of any confession that police might obtain through questioning. Thus, like the Fourth Amendment exclusionary rule, these issues tend to draw defense attorney attention toward raising claims about process rather than about substance. ${ }^{91}$

\footnotetext{
${ }^{85}$ See generally Paul G. Cassell, Protecting the Innocent from Lost Confessions and False Confessions - And from Miranda, 88 J. CRIM. L. \& CRIMINOLOGY 497 (1998). .

${ }^{86}$ Steven B. Duke, Does Miranda Protect the Innocent or the Guilty?, 10 CHAP. L. REv. 551, 566-67 (2007); see also Ronald J. Allen, Miranda's Hollow Core, 100 Nw. U. L. REV. 71 (2006).

87 Tonja Jacobi, Miranda 2.0, available at http://papers.ssrn.com/sol3/papers.cfm?abstract_id=2656405.

${ }^{88}$ See Cassell, supra note 85, at 539-40.

${ }^{89}$ Christopher Slobogin, Towards Taping, 1 OHIO ST. J. CRIM. L. 309 (2003) (arguing that Miranda has had an "immunizing" effect on deceptive interrogation tactics); OfFICE OF LEGAL POLICY, U.S. DEP'T OF JUSTICE, REPORT TO THE ATTORNEY GENERAL ON THE LAW OF PRETRIAL INTERROGATION 97-98 (1986), reprinted in 22 U. Mich. J.L. REFORM 437 (1989).

${ }^{90}$ See 39 Geo. L.J. AnN. Rev. CRIM. PRO. 1, 179-99 (2014) (collecting approximately 400 recent federal court of appeals cases on Miranda issues).

${ }^{91}$ See Stuntz, supra note 76, at 44 (advancing the argument that Miranda doctrine causes shift of attention away from defendants with factual issues to raise and toward defendants with procedure claims to raise).
} 
Miranda has also turned the attention of trial judges away from questions of the reliability of confessions and toward questions about police compliance with the Miranda rules. As Professor Welsh White has observed, before Miranda, reliability "played an important role in our constitutional jurisprudence .... [ [Since Miranda], however, courts and legal commentators have largely ignored issues relating to untrustworthy confessions." ${ }^{92}$ To be sure, as a matter of black letter law, the Miranda procedural requirements were piled on top of traditional voluntariness requirements. But as a practical matter, judicial attention is a scarce resource. Miranda has created a triumph of formalism. ${ }^{93}$ Prioritizing one set of claims (Miranda compliance) has inevitably reduced scrutiny of the others - to the disadvantage of innocent defendants. As Professor Steven Duke has explained, not only is Miranda "virtually useless", but it "replaced a vibrant and developing voluntariness inquiry that took into account the vulnerabilities of the particular suspect as well as the inducement and conditions of the interrogation." "94 The bottom line is that "not only has Miranda allowed the police to disregard actual voluntariness, it has enabled the courts to be equally unconcerned with actual innocence." 95

One last injury to the innocent defendants is worth noting. Good reasons exist for believing that Miranda has significantly hampered the ability of police officers to obtain confessions from guilty criminals. ${ }^{96}$ This has not only harmed law enforcement's ability to convict guilty criminals but also the opportunity of innocent individuals to use those confessions to exonerate themselves. ${ }^{97}$ For example, Professor Gross has noted that the number of exonerations when the actual criminal confessed declined sometime between the mid-1950s and the early 1970s. ${ }^{98}$ Gross cites among the possible causes the Miranda decision, which "may

\footnotetext{
${ }^{92}$ Welsh S. White, False Confessions and the Constitution: Safeguards Against Unworthy Confessions, 17 HaRV. C.R.-C.L. L. REV. 105, 156 (1997).

${ }^{93}$ Joseph D. GRANO, CONFESSIONS, TRUTH AND the LAW 206-16 (1996).

${ }^{94}$ Duke, supra note 86 , at 564 .

95 Jacobi, supra note87, at 12.

${ }^{96}$ See, e.g., Paul G. Cassell, Miranda’s Social Costs: An Empirical Reassessment, 90 Nw. U. L. REv. 387 (1996); Paul G. Cassell \& Richard Fowles, Handcuffing the Cops? A Thirty-Year Perspective on Miranda's Harmful Effects on Law Enforcement, 50 STAN. L. ReV. 1055 (1998); Paul G. Cassell \& Bret S. Hayman, Police Interrogation in the 1990s: An Empirical Study of the Effects of Miranda, 43 UCLA L. REV. 839 (1996). These conclusions are not universally accepted. Compare, John J. Donohue III, Did Miranda Diminish Police Effectiveness?, 50 STAN. L ReV. 1147 (1998) (critiquing the validity of the data used to correlate Miranda with diminished clearance), with Paul G. Cassell, Falling Clearance Rates After Miranda: Coincidence or Consequence?, 50 STAN. L. REV. 1181 (1998) (responding to these criticisms).

${ }^{97}$ See Cassell, supra note 85, at 550-52.

${ }^{98}$ Samuel R. Gross, Loss of Innocence: Eyewitness Identification and Proof of Guilt, 16 J. LEGAL STUD. 395, 430-
} 
result in some reduction in the number of confessions." 99 Thus, by impairing the system's ability to get to the truth in cases, Miranda has caused the innocent to suffer.

A system that respects the constitutional right against self-incrimination, while at the same time providing greater protection for innocent suspects, could be easily designed. There appears to be wide agreement that video recording interrogations would offer far greater protection for innocent suspects than does the current Miranda regime. ${ }^{100}$ I made a proposal long ago for substituting video recording of police questioning as a substitute for Miranda, based in part in the need to protect the innocence. ${ }^{101}$ Other commentators have proposed that recording should supplement Miranda. ${ }^{102}$ A fair number of jurisdictions are moving forward with requiring video recording of at least some interrogations, ${ }^{103}$ although recording is often left to the discretion of police officers or mandated only for very serious crimes. The "Innocence Movement” could speed the adoption of this important reform if they would highlight the extent to which Miranda does not offer effective protection to the innocent and suggest that, instead, we should use video recording.

Moving in this direction has the great advantage of not interfering with the conviction of the guilty. It appears that video recording does not greatly interfere with the ability of law enforcement to obtain confessions and, of course, if the Miranda rules were relaxed or replaced by video recording, there would be an unambiguous boost to prosecution efforts. As a result, this kind of reform would not only avoid the tradeoffs discussed above, but would indeed be a true "win-win": more convictions of the guilty, while fewer convictions of the innocent.

\section{Requiring All Defense Attorneys to Directly Ask Their Clients, "Did You Commit the Crime?” and Aggressively Investigate Claims of Actual Innocence}

\footnotetext{
31 (1987).

99 See Cassell, supra note 85,. at 51. For reasons to think that Miranda is the most likely cause of this drop in confessions, see Cassell, Miranda’s Social Costs, supra note 96, at 285.

100 See Yale Kamisar, On the Fortieth Anniversary of the Miranda Case: Why We Needed It, How We Got It-and What Happened To It, 5 OHIO. ST. J. CRIM. L. 163, 189-90 (2007).

${ }^{101}$ See Cassell, Miranda's Social Costs, supra note 96, at 486-92.

102 See, e.g., Lisa Lewis, Rethinking Miranda: Truth, Lies, and Videotape, 43 GonZ. L. REV. 199 (2007); Lisa C. Oliver, Mandatory Recording of Custodial Interrogations Nationwide: Recommending a New Model Code, 39 SUFFOLK U. L. REV. 263 (2005).

103 See Alan M. Gershel, A Review of the Law in Jurisdictions Requiring Electronic Recording of Custodial Interrogations, 16 RICH. J.L. \& TECH. 9 (2010); Michael Schmidt, In Policy Change, Justice Dept. to Require Recording of Interrogations, N.Y. TIMES, May 22, 2014.
} 
A critical resource in the efforts to prevent wrongful convictions is defense attorneys.

Yet the great bulk of innocence literature seems to focus attention on prosecutors as the source of the problems. ${ }^{104}$ For example, in his Chapter in this book, Professor George Thomas calls prosecutors "the thin last line protecting the innocent." 105 And he is surely right that prosecutors have critical steps they can take to reduce wrongful convictions, such as by fully discharging their Brady obligations to produce exculpatory evidence (a point I have pressed elsewhere). ${ }^{106}$

But the Innocence Movement has largely overlooked what may be an even more important bulwark against false convictions: defense attorneys. Unfortunately, the mindset of the defense bar toward the question of whether their clients are in fact guilty has been aptly described as one of "staggering indifference." 107 Indeed, it is sometimes even argued that it is inconsistent with ethical obligations for defense counsel to focus on innocence. ${ }^{108}$ Defense attorneys simply cannot consider whether their clients are guilty, it is argued, because doing so would impair the quality of the representation they provide. ${ }^{109}$ And, more broadly it is argued, focusing on innocence issues may distract society from dealing with mass incarceration and other issues associated with the guilty. ${ }^{110}$

I am unconvinced. Innocent persons ensnared in the criminal justice system have a stronger claim to our attention than do the guilty. If we want to structure an "innocentric" criminal justice system that gives highest priority to preventing the conviction of the innocent, ${ }^{111}$ defense attorneys must be involved. In fact, defense attorneys-who (unlike prosecutors) have constant and direct access to defendants-may be uniquely positioned to identify a miscarriage of justice before it happens and take steps to prevent it. They are also well-poised to increase the “diagnosticity” of the system, by helping to flag the relatively small percentage of cases in the system genuinely involving factual innocence claims. ${ }^{112}$

\footnotetext{
104 See, e.g., Dana Carver Boehm, The New Prosecutor's Dilemma: Prosecutorial Ethics and the Evaluation of Actual Innocence, 2014 UTAH L. REV. 613.

105 George Thomas, Prosecutors: The Thin Last Line Protecting the Innocent, infra.

106 See Cassell, supra note 3, at 1084-86.

107 Barbara Allen Babcock, Defending the Guilty, 32 CLEV. ST. L. REV. 175, 180 (1983).

108 Robert Mosteller, Why Defense Attorneys Cannot, But Do, Care About Innocence, 50 SANTA ClARA L. REV. 1 (2010).

109 See id.; see also Margaret Raymond, The Problem with Innocence, 49 CLEV. ST. L. REV. 449 (2001).

110 Abbe Smith, In Praise of the Guilty Project: A Criminal Defense Lawyer's Growing Anxiety About Innocence Projects, 13 U. PA. J.L. \& SoC. CHANGE 315, 329 (2010).

111 See Medwed, supra note 41.

${ }^{112}$ Cf. W. Tucker Carrington, “A House Divided”: A Response to Professor Abbe Smith's In Practice of the Guilty Project: A Criminal Defense Lawyer's Growing Anxiety About Innocence Projects, 15 U. PA. J.L. \& SoC. CHANGE
} 
Here is one example of how we might think about reorienting defense counsel toward innocence issues. Many defense attorneys do not directly ask their clients whether they are guilty of the crime charged. ${ }^{113}$ This ignorance may permit defense attorneys to perhaps raise defenses that might otherwise be barred by rules of legal ethics. ${ }^{114}$ But why should we give defense counsel such freedom if we are trying to structure a criminal justice system that focuses on innocence? It is hard to see what larger societal interest is served by allowing counsel to move forward in ignorance of this important fact. It may be true, as some defense advocates have argued, that a defense attorney can never be sure whether her client is telling the truth when a defendant claims to be innocent. ${ }^{115}$ But requiring defense attorneys to at least ask that basic question would serve the valuable function of putting this issue squarely out in the open, helping innocent defendants. And the only "cost" is that defense counsel for some guilty defendants might be limited in the kinds of arguments that can be advanced at trial-a cost that society surely ought to be willing to bear to have a system that more accurately sorts the innocent from the guilty.

Simply requiring the defense attorney to ask this straightforward question probably would not make much of a change in the current system. Part of the current criminal justice game seems to be for defendants to deny their involvement in a crime-at least at the start of a case. For example, Professor Robert Mosteller reports that, when he was a defense attorney, virtually all of his clients claimed to be innocent until he recited the advantages of a specific plea offer; at that point, they conceded their guilt. ${ }^{116}$ In light of this fact, maybe defense attorneys should be required not only to ask their clients if they committed the crime but to also explore more thoroughly whether a defendant is truly guilty or innocent. This requirement could be enforced by a rule that only if a defendant admits he is guilty would a defense attorney be permitted to explore a standard plea bargain. ${ }^{117}$ Such a requirement might promote more frank and open

\footnotetext{
1, 23 (2011) (providing an illustration of a case in which defense counsel obtained a dismissal from a prosecutor by sharing exculpatory evidence collected by defense investigators).

113 Cassell, supra note 3, at 1068-69.

114 See Model Rules of Prof'l Conduct R. 3.3(a)(3). But cf. Harry I. Subin, The Criminal Lawyer's “Different Mission": Reflections on the "Right” To Present a False Case, 1 GEO. J. LEGAL ETHICS 125 (1987) (suggesting that there are few limits on the defense and criticizing this view).

115 See Mosteller, supra note 108, at 41. Most defendants presumably will admit they are guilty. Cf. Poveda, Estimating Wrongful Convictions, 18 JUST. QUART. 689, 701 (2001) (noting that about 15\% of convicted inmates claimed to have not committed the crime for which they had been imprisoned, implying an $85 \%$ admission rate).

116 See Mosteller, supra note 78, at 954.

117 A defense attorney could still explore an Alford plea for an “innocent” defendant. See North Carolina v. Alford,
} 
discussion between defense attorneys and their clients about whether they were involved in the crime.

Forcing defense attorneys to truly attempt to learn whether their clients are guilty or innocent would create a real advantage: it would give the criminal justice system one more opportunity to begin sorting innocent defendants from guilty ones through the one person who has the best access to important information-the defendant. Professor Mosteller may properly complain about how defense attorneys have difficulties obtaining access to witnesses and other forms of evidence, ${ }^{118}$ but the barriers to information are not all one-sided. Prosecutors are usually precluded from talking to defendants once legal counsel enters the scene. But defendants are obviously in a unique position to provide information that can sort the guilty from the innocent. If defendants can be induced to provide more thorough information to their attorneys about whether they are innocent or guilty, then the system can more effectively protect against wrongful conviction.

With the innocence issue directly on the table for discussion, how should defense counsel proceed when her client reports that he is innocent? Professor Mosteller rightly bristles at the suggestion that there should be some sort of "second-class treatment" of defendants who state clearly that they are guilty. ${ }^{119}$ He explains quite nicely that defense counsel have important duties to perform in the criminal justice system, even when performing the far more common duty of defending those who have in fact committed the crimes charged against them. But he interestingly goes on to discuss the idea that perhaps individual defense attorneys - or the criminal justice system more broadly-should try to devote additional resources to cases in which a defendant has a good claim of actual innocence. ${ }^{120}$ Of course, defense attorneys —and the system-are not well-positioned to do this if the defendant is not even asked whether he is in fact innocent.

If a defendant claims to be innocent, as a first step defense counsel obviously ought to adequately investigate the claim. Presumably adequate defense investigation happens in many

\footnotetext{
400 U.S. 25 (1970). But typically the sort of concessions that prosecutors are willing to offer for such a plea are less than that offered for a full-blown guilty plea.

${ }^{118}$ See Mosteller, supra note 78, at 941-43 (discussing “limited defense access to witnesses and evidence”).

119 Mosteller, supra note 108 , at 7.

${ }^{120}$ Id. at 68-69.
} 
cases, ${ }^{121}$ regardless of whether a defendant claims to be innocent or guilty. But if some defense attorneys are not squarely raising the innocence issue because they think ignorance is tactically useful, they may end up missing a chance to discover exculpatory evidence that could set a defendant free. ${ }^{122}$

Following such an investigation, defense counsel should obviously rely on the procedures available in our criminal justice system for presenting a defense. Within our traditional structure, defense attorneys have many tools that they can employ in the defense of innocent clients.

But in reviewing cases of wrongful conviction over the years, one omission from the defense repertoire has always puzzled me. I have always wondered why, in a rare case where a defense attorney believes she is representing a truly innocent client, she almost invariably fails to bring the prosecutor into the discussion. The wrongful conviction literature suggests it is unusual for a defense attorney to communicate her specific concerns directly to a prosecutor. ${ }^{123}$ Perhaps this is part of a larger culture of distrust between prosecutors and defense attorneys that appears to afflict at least some jurisdictions. ${ }^{124}$ But direct communication on this issue needs to be strongly encouraged. ${ }^{125}$

It would, of course, be naive to think that defense counsel reports to prosecutors could prevent every wrongful conviction of an innocent defendant. But I am surprised to discover that defense counsel so rarely employ this approach. Perhaps an unfortunate reason is that defense attorneys behave in the way that Mosteller suggests: they simply do not view their job as having much to do with guilt or innocence. ${ }^{126}$ If defense attorneys proceed in this way, they never learn whether they have an innocent defendant for a client as opposed to a guilty one. This agnostic approach may help to avoid burnout on the job or allow for an increased feeling of self-worth, as

\footnotetext{
${ }^{121}$ But cf. Ion Meyn, Discovery and Darkness: The Information Deficit in Criminal Disputes, 79 BRoOK. L. REV. 1091 (2014) (arguing that certain structural defects in the criminal justice system mean that defense counsel cannot adequately investigate); Andrew D. Leipold, How the Pretrial Process Contributes to Wrongful Convictions, 42 AM. CRIM. L. REV. 1123 (2005) (arguing that current pretrial procedures prevent innocent persons from collecting exculpatory evidence).

122 See Abbe Smith, Defending the Innocent, 32 ConN. L. REV. 485, 510 (2000) (reporting an example of a seemingly delusional defendant blaming thefts on a "chicken man"; defense investigation discovers that man in a chicken suit perpetrated the crimes).

123 See Carrington, supra note 112, at 23 (referring to the "unorthodox" approach of a defense team in a murder case sharing exculpatory evidence with the prosecutor).

${ }^{124}$ See Lissa Griffin \& Stacy Caplow, Changes to the Culture of Adversarialness: Endorsing Candor, Cooperation and Civility in Relationships Between Prosecutors and Defense Counsel, 38 HASTINGS CONST. L.Q. 845 (2011).

${ }^{125} \mathrm{Id}$. at 869.

${ }^{126}$ Mosteller, supra note 108, at 60-64; accord Babcock, supra note 107, at 180.
} 
some have argued in justification. ${ }^{127}$ But this strikes me as a something of a cop-out, leading the Innocence Movement to point fingers first at errant prosecutors and rogue police officers while too often ignoring the role of ignorant defense attorneys. If we wish to leave no stone unturned in our efforts to prevent conviction of the innocent, it is time to broaden our perspective to include defense attorneys as those who have special responsibility - and special abilities - to prevent wrongful convictions. ${ }^{128}$

\section{$\underline{\text { Conclusion }}$}

Preventing wrongful conviction of the innocent is a fundamental priority of our criminal justice system. But it is obviously not the system's only goal. Efforts to prevent conviction of the innocent should avoid interfering with other objectives, most prominently the need to convict the guilty and prevent the suffering of future crime victims. Comparing even rough estimates of the risk of a person being wrongfully sent to prison for committing a violent crime with the risk of becoming a violent crime victim suggests that the current tradeoffs between the two may incline dramatically toward increasing victimization.

But there are some kinds of reforms that can avoid debate about these tradeoffs - true "win-win" measures that simultaneously reduce the number of innocents wrongfully convicted while increasing (or least not decreasing) the number of violent criminals sent to prison. This Chapter lays out a few such possibilities, including confining habeas relief to those with claims of factual innocence, replacing the exclusionary rule with a civil damage remedy, moving confession law away from technical Miranda procedures, and requiring defense attorneys to explore their clients' guilt or innocence. If we are truly committed to protecting the innocent, we can and should take such specific steps. We can reduce the risk of wrongfully convicting the innocent without setting free the guilty.

\footnotetext{
127 See generally Barbara Allen Babcock, Book Review, 53 GEO. WASH. L. REV. 310, 315 (1984).

128 One way to hold defense attorneys accountable for wrongful convictions would be through civil suits against them. Recent cases seem to be broadening defense liability in this area. See, e.g., Dombrowski v. Bulson, 915 N.Y.S.2d 778 (4th Dep’t 2010) (nonpecuniary loss damages are available for criminal defendant's loss of liberty due to attorney malpractice); cf. Kevin Bennardo, Note, A Defense Bar: The "Proof of Innocence" Requirement in Criminal Malpractice Claims, 5 OHIO ST. J. CRIM. L. 341 (2007) (proposing that defendants should not be required to prove that they are innocent to proceed with criminal malpractice claims).
} 